\title{
The Role Of Interest Rate Reforms In Lesotho: An Empirical Investigation
}

Nicholas M. Odhiambo, University of South Africa, South Africa

\begin{abstract}
This paper examines the efficacy of interest rate reforms in Lesotho during the period 1972-2009. The study attempts to answer one critical question: Does interest rate liberalisation positively or negatively affect financial deepening in Lesotho? The study examines this linkage by regressing the financial depth variable on real income, deposit rate, foreign aid, the expected inflation and the lagged value of financial depth. Using the ARDL-Bounds testing approach, the study finds that there is a positive relationship between interest rate reforms and financial deepening in Lesotho, meaning that interest rate reforms lead to financial deepening in Lesotho. The results apply regardless of whether the financial deepening model is estimated in the short run or in the long run. Other results indicate that: i) An increase in real GDP has a positive effect on financial deepening in Lesotho - both in the short run and in the long run; ii) expected inflation has a positive effect on financial deepening in the short run; and iii) foreign aid has a negative effect on financial deepening in Lesotho in the short run.
\end{abstract}

Keywords: Lesotho; interest rate reforms; financial deepening; ARDL-bounds testing approach

\section{INTRODUCTION}

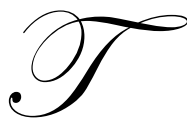

he positive role of interest rate reforms has gained support from both the empirical and theoretical fronts in recent years. The argument that advocates that financial liberalisation leads to financial development and eventually to economic growth is based on the theoretical framework and analytical underpinning of McKinnon (1973) and Shaw (1973). While Shaw (19730 emphasised the debt intermediation channel, McKinnon's (1973) main transmission mechanism was based on the so-called complementarity theory. According to McKinnon (1973) and Shaw (1973), a repressed financial sector interferes with economic development in three ways. Firstly, in a repressed economy the savings vehicles are not well developed and the returns on savings are either negative or unstable. Secondly, financial intermediaries do not allocate savings efficiently amongst competing uses. Thirdly, firms are discouraged from investing because of poor financial policies, which tend to reduce returns on investment. This makes investments uncertain and, as a result, growth is retarded (McKinnon, 1973; and Shaw, 1973). Unlike financial repression, financial liberalisation enables savers to switch some of their savings from unproductive real assets to financial assets - hence expanding the supply of credit in the economy. In this way, financial liberalisation plays a crucial role in financial deepening.

Unfortunately, very few empirical studies have been conducted in sub-Saharan African countries on the role of financial liberalisation in general, and interest rate liberalisation in particular. The empirical studies on the effects of interest rate liberalisation on financial deepening in countries such as Lesotho are almost none-existent. Some of the few studies that have been conducted on this subject include Ikhide (1992), Mosley (1999) and Odhiambo (2005). Ikhide (1992), for example, conducts a study on financial deepening, credit availability and the efficiency of investment in 17 African countries. In the main, the author finds real rate of interest to have a positive effect on financial deepening in 12 out of the 17 countries. Mosley (1999), whilst examining the impact of financial liberalisation on the access to rural credit in a number of countries, finds that the impact of financial sector reforms on financial depth, as measured by bank deposits and M2 as a percentage of GDP, varies between countries. 
Odhiambo (2005) also examines the role of interest rate liberalisation on financial deepening in three SSA countries, namely South Africa, Tanzania and Kenya using cointegration and error-correction mechanisms. The author finds a positive and significant relationship between positive interest rates and financial deepening in all three countries studied. According to the author, these results provide abundant support for the positive role of financial liberalisation on financial deepening in the three study countries.

The current study attempts to examine the dynamic relationship between positive interest rates and financial deepening in Lesotho. The study attempts to answer one critical question. Does interest rate liberalisation spur financial deepening in Lesotho? The rest of the paper is structured as follows: Section 2 discusses the dynamics of interest rate reforms in Lesotho. Section 3 deals with the empirical model specification, estimation techniques and presents the empirical results. Section 4 concludes the study.

\section{THE DYNAMICS OF INTEREST RATE REFORMS IN LESOTHO}

Lesotho is a late starter in financial sector liberalisation and the reforms are still on-going. The majority of the reforms were implemented in the 1990s. These reforms were aimed at improving the monetary control of the Central Bank by switching from direct to indirect monetary policy instruments with a view to establishing a more market-oriented financial system. Until the 1990s, the financial sector in Lesotho was quantitatively controlled by the government. In particular, the policy of administrative interest rate determination was practised widely. This practice discouraged bank intermediation, and resulted in large spreads between lending and deposit rates. While setting administrative interest rates, the Central Bank of Lesotho uses the South African interest rates as a benchmark. This is done specifically in order to limit interest rate differentials between South Africa and Lesotho, and to discourage cross border capital mobility from Lesotho to South Africa. Even though the Common Monetary Area (CMA) allows free movement of capital among member countries, some capital controls are exercised in Lesotho (see Matlanyane, 2002). Financial institutions, for example, are required to hold at least $85 \%$ of their local liabilities within the country and no more than $15 \%$ abroad. The main aim of this ruling is to ensure that financial institutions invest the bulk of their financial assets domestically.

With the exception of the savings deposit rate, all interest rates in Lesotho were liberalised in 1993. The saving rate, however, continued to be set by the Central Bank even after 1993, and commercial banks were expected to set their own saving rates based on the minimum saving rate set by the Central Bank (see Salialia and Tlali, 1996). In December 1994, the Central Bank of Lesotho issued its commercial paper with the aim of supplementing the supply of treasury bills by mopping up any excess liquidity in the commercial banking system. However, in 1996 this instrument was withdrawn because many commercial banks resorted to use this instrument as an alternative to direct lending. In 1998, a number of financial reforms were undertaken culminating in the liberalisation of deposit interest rates and the use of indirect monetary policy. In 1999, the Government of Lesotho repealed and replaced the Financial Institutions Act of 1973 with the Financial Institutions Act 1999. The main aim of this move was to strengthen the supervision and regulation of banks and non-banks financial institutions, following the liberalisation of the financial sector in 1998. Specifically, the act paved the way for the enforcement of prudential banking standards and practices in Lesotho based on internationally accepted standards such as the Basel core principles for effective Bank Supervision (see Central Bank of Lesotho, Supervision Department Annual Report 2002). Currently the Central Bank of Lesotho, through its Supervision Department, monitors the activities of the licensed financial institutions countrywide. In 2003, further financial reforms were undertaken leading to some limited capital account liberalisation (see Lesotho Economic Review, 2003). Although the main aim of financial reforms in Lesotho was to enhance financial intermediation by broadening the range of money market instruments, evidence shows that by and large, the performance of the banking sector deteriorated significantly following the implementation of the financial reforms (see also Matlanyane, 2002). This trend was especially manifested in a series of bank failures. For example, Lesotho Bank, which had been experiencing some signs of distress since the 1990s, had to be liquidated. Likewise, the Agricultural Development Bank had to be closed in 1998, following its poor performance due to high operating costs (for more details see Matlanyane, 2002). Figures 1 and 2 show the trends of selected interest rates and the inflation rate in Lesotho, during the period 1981-1996, and the period 20002005 , respectively. 


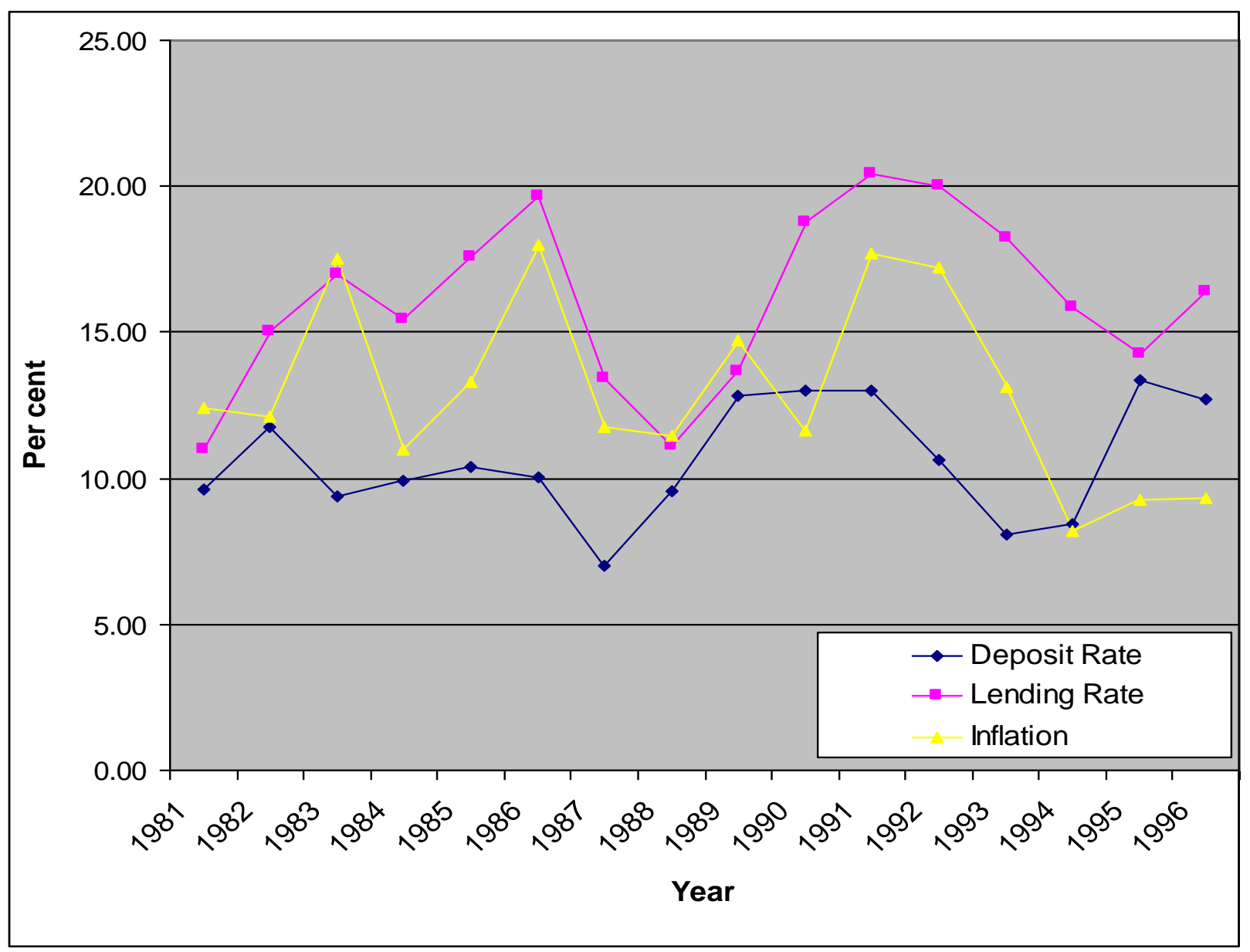

Figure 1: Trends Of Interest Rates And The Inflation Rate In Lesotho (1981-1996) Source: WDI (2006) 


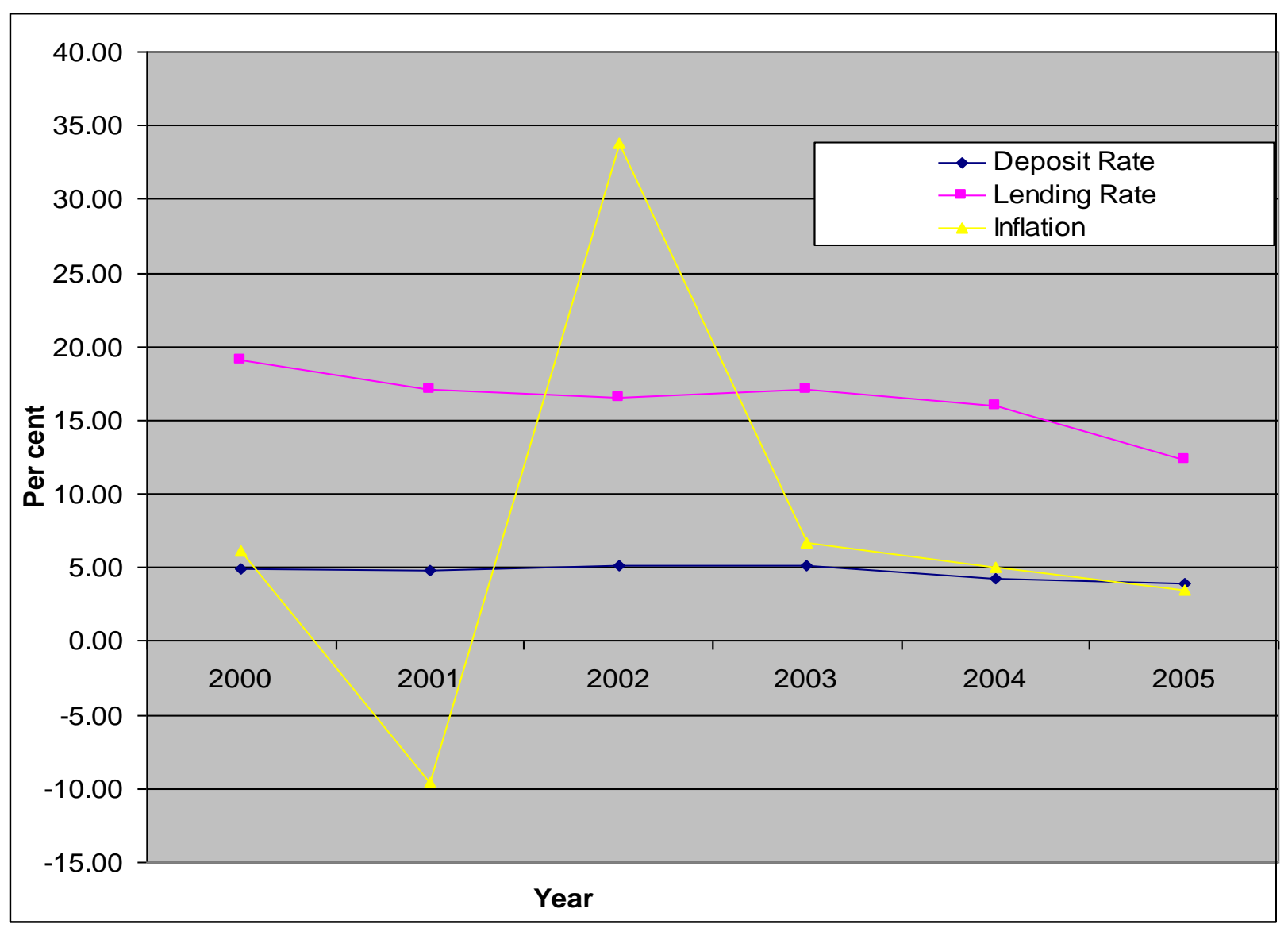

Figure 2: Trends Of Interest Rates And The Inflation Rate In Lesotho (2000-2005) Source: WDI (2006)

\section{ESTIMATION TECHNIQUES AND EMPIRICAL RESULTS}

\subsection{Empirical Model Specification}

In this section, the relationship between interest rate liberalisation and financial deepening is examined by regressing the financial depth variable on real income, deposit rate, expected inflation and the lagged value of financial depth. The financial deepening model used in this study can be expressed as follows:

$\log (\mathrm{FD})_{\mathrm{t}}=\beta_{0}+\beta_{1} \log \mathrm{y}+\beta_{2} \log \mathrm{D}-$ rate $+\beta_{3} \log \mathrm{Pe}+\beta_{3} \log \mathrm{AID}+\beta_{5} \log (\mathrm{FD})_{\mathrm{t}-1}+\mathrm{Et}$

Where: $(\mathrm{FD})_{\mathrm{t}} \quad=$ Financial depth variable proxied by M2/GDP; $\mathrm{y}=$ real income; $\mathrm{D}-$ rate $=$ deposit rate (nominal); $\mathrm{Pe}=$ expected inflation; $\mathrm{AID}=$ foreign aid; $(\mathrm{FD})_{\mathrm{t}-1}=$ financial depth lagged once.

The rationale for including different variables in the financial deepening model is based on the following theoretical arguments: The inclusion of deposit rate is expected to capture the impact of interest rate liberalisation on financial deepening. The coefficient of deposit rate in the financial deepening model is, therefore, expected to be positive and statistically significant. The inclusion of the inflation rate is meant to capture the impact of inflation on the various components of money. There has been an argument that inflation adversely affects the holding of all classes of financial assets and not just a narrow class. In addition, it has been argued that inflation will tend to encourage the holding of currency and discourage the holding of quasi-money (see also Odhiambo, 2005; Ikhide, 1992). According to English (1999), a higher inflation rate encourages households to substitute purchased 
transactions services for money balances, thereby boosting the financial sector. The coefficient of inflation in this study is, therefore, expected to be positive and statistically significant. The inclusion of real GDP is supported by the life cycle hypothesis and the coefficient of the variable is expected to be positive and statistically significant.

\subsection{ARDL-Bounds Testing Approach}

In this study the recently developed Autoregressive Distributed Lag (ARDL) - Bounds testing approach is used to examine the linkage between interest rate liberalisation and financial deepening in Lesotho. The ARDL modelling approach was originally introduced by Perasan and Shin (1999) and later extended by Perasan et al. (2001). Unlike other cointegration techniques, the ARDL approach can be applied regardless of whether the underlying regressors are integrated of order one [I(1)], order zero [I(0)] or fractionally integrated. In addition, the ARDL technique provides unbiased estimates of the long-run model and valid t-statistics even when the sample size is small or some of the regressors are endogenous (see also Harris and Sollis, 2003; Odhiambo, 2010). The ARDL model used in this study can be expressed as follows:

$$
\begin{aligned}
& \Delta \operatorname{InFD}_{t}=\alpha_{0}+\sum_{i=1}^{n} \alpha_{1 i} F D_{t-i}+\sum_{i=0}^{n} \alpha_{2 i} \Delta \operatorname{InD}-\text { rate }_{t-i}+\sum_{i=0}^{n} \alpha_{3 i} y_{t-i}+\sum_{i=0}^{n} \alpha_{4 i} \Delta \operatorname{InPe}_{t-i} \\
& +\sum_{i=0}^{n} \alpha_{5 i} \Delta \operatorname{In} \operatorname{AID}_{t-i}+\alpha_{6} \operatorname{InFD}_{t-1}+\alpha_{7} D-\text { rate }_{t-1} \alpha_{8}+y_{t-1}+\alpha_{9}{\operatorname{In} P e_{t-1}+\alpha_{10} \operatorname{In}_{A I D} D_{t-1}}_{+} \mu_{t}
\end{aligned}
$$

The bounds testing procedure is based on the joint F-statistic (or Wald statistic) for cointegration analysis. The asymptotic distribution of the F-statistics is non-standard under the null hypothesis of no cointegration between examined variables. The null hypothesis of no cointegration among the variables in equation (1) is $\left(H_{0}: \alpha_{6}=\alpha_{7}=\alpha_{8}\right.$ $\left.=\alpha_{9}=\alpha_{10}=0\right)$ against the alternative hypothesis ( $\left.11: \alpha_{6} \neq \alpha_{7} \neq \alpha_{8} \neq \alpha_{9} \neq \alpha_{10} \neq 0\right)$.

Pesaran et al. (2001) report two sets of critical values for a given significance level. One set of critical values assumes that all variables included in the ARDL model are I $(0)$, while the other is calculated on the assumption that the variables are I(1). If the computed test statistic exceeds the upper critical bounds value, then the Ho hypothesis is rejected. If the F-statistic falls into the bounds, then the cointegration test becomes inconclusive. If the F-statistic is lower than the lower bounds value, then the null hypothesis of no cointegration cannot be rejected.

\subsection{Empirical Analysis}

\subsubsection{Stationarity Tests}

The results of the stationarity tests in levels are presented in Tables 1 and 2.

Table 1: Stationarity Tests Of All Variables In Levels: DF -GLS Test

\begin{tabular}{|c|c|c|}
\hline Variable & NO TREND & TREND \\
\hline LM2/GDP & -0.912830 & -1.848746 \\
\hline y/N & -0.562084 & -1.840710 \\
\hline LD-rate & -1.472030 & -1.889649 \\
\hline LPe & -0.578737 & -1.847204 \\
\hline LAID & -1.037512 & -1.232470 \\
\hline
\end{tabular}


Table 2: Stationarity Tests of Variables in Levels - PHILIP-PERRON (PP) TEST

\begin{tabular}{|c|c|c|}
\hline & NO TREND & TREND \\
\hline LM2/GDP & & -1.626771 \\
\hline y/N & -1.50500 & -2.076413 \\
\hline LD-rate & -1.971966 & -2.375111 \\
\hline Lpe & -2.042213 & -2.472391 \\
\hline LAID & -1.621709 & -2.029513 \\
\hline
\end{tabular}

Note: The truncation lag for the PP tests is based on Newey and West (1987) bandwidth.

The results presented in Tables 1 and 2 show that all the variables in the financial deepening model are non-stationary in levels. The unit root tests applied to the variables in levels reject the null hypothesis of stationarity of all the variables used in the financial deepening model. The variables are, therefore, differenced once in order to perform stationary tests in first difference. The results of the stationarity tests of variables in first difference are presented in Tables 3 and 4.

Table 3: Stationarity Tests of all Variables in first Difference: DF-GLS Tests

\begin{tabular}{|c|c|c|}
\hline Variable & NO TREND & TREND \\
\hline DLM2/GDP & $-3.068601 * * *$ & $-3.195782^{* *}$ \\
\hline DLy/N & $-4.984839^{* * *}$ & $-5.013430^{* * *}$ \\
\hline DLD-rate & $-8.379740^{* * *}$ & $-8.423585^{* * *}$ \\
\hline DLPe & $-7.480152^{* * *}$ & $-7.803724 * * *$ \\
\hline DLAID & $-3.306874 * * *$ & $-4.066898^{* * *}$ \\
\hline
\end{tabular}

Note: $* * *$ and $* *$ denote $1 \%$ and $5 \%$ level of significance, respectively.

Table 4: Stationarity Tests of Variables in first Difference - PHILIP-PERRON (PP) TEST

\begin{tabular}{|c|c|c|}
\hline Variable & NO TREND & TREND \\
\hline DLM2/GDP & $-3.056230^{* *}$ & $-4.389036^{* * *}$ \\
\hline DLy/N & $-4.844742 * * *$ & $-4.787471 * * *$ \\
\hline DLD-rate & $-8.273817 * * *$ & $-8.179991 * * *$ \\
\hline DLpe & $-7.394150 * * *$ & $-7.608780^{* * *}$ \\
\hline DLAID & $-5.368639^{* * *}$ & $-5.489176^{* * *}$ \\
\hline
\end{tabular}

Note: The truncation lag for the PP tests is based on Newey and West (1987) bandwidth.

$* * *$ and $* *$ denote $1 \%$ and $5 \%$ level of significance, respectively.

The results reported in Tables 3 and 4 show that after differencing the variables once, all the variables included in the financial deepening model are confirmed to be stationary. The DF-GLS and Phillips-Perron tests applied to the first difference of the data series reject the null hypothesis of non-stationarity for all the variables used in the model. It is, therefore, worth concluding that all the variables are integrated of order one.

\subsubsection{Bounds F-Test For Cointegration}

Having established that the variables are of the same order of integration, the next procedure is to test the possibility of cointegration among the variables used in the model. For this purpose, the recently introduced ARDLbounds testing approach is used. The ARDL-Bounds testing procedure involves two steps. In the first step, the order of lags on the first differenced variables in the financial deepening equation is obtained from the unrestricted models by using the Akaike Information Criterion (AIC) and the Schwartz Bayesian Criterion (SBC). The results of the above tests (not reported here) show that the optimal lag for the financial deepening function is lag 2 . Having 
established the optimal lag length the next step is to apply the bounds F-test in order to establish the long-run relationship between the variables included in the equation. The results of the bounds test are reported in Table 5 .

Table 5: ARDL Bounds Test for Cointegration Analysis

\begin{tabular}{|c|c|c|}
\hline \multicolumn{2}{|c|}{ Computed F- Statistic: 4.79086} & \multicolumn{2}{c|}{ Upper } \\
\hline Critical Bounds (1\%) & Lower & 5.06 \\
\hline Critical Bounds (5\%) & 3.74 & 4.01 \\
\hline
\end{tabular}

Note: Critical values are taken from Tale C1(iii) of Pesaran et al (2001): Unrestricted intercept and no trend in the model.

The results of the Bounds test presented in Table 5 show that the computed F-statistic (4.79086) exceeds the upper bound critical value (4.01) at the $5 \%$ level of significance. This indicates that there is a stable long-run relationship between the financial deepening variable and its determinants.

\subsubsection{Unrestricted Error-Correction Model (UECM)}

The results presented in the preceding section indicate that cointegration of the financial deepening model has been accepted. The next step is to derive the long-run and short-run coefficients of the explanatory variables in the financial deepening model by using the simplest UECM. Table 6 gives the results of the simplest UECM based on Henry's general-to-specific approach (1991).

Table 6: The Estimated UECM

\begin{tabular}{|c|c|c|c|}
\hline Variable & \multicolumn{2}{|c|}{ Coefficient } & t-Statistic \\
\hline \multicolumn{4}{|c|}{ Short-Run Relationship } \\
\hline$\overline{\text { D(LM2_GDP01(-3)) }}$ & & $4.437350 * * *$ \\
\hline D(LD_RATE01) & \multicolumn{2}{|c|}{0.264185} & $3.625006 * * *$ \\
\hline D(LD_RATE01(-2)) & \multicolumn{2}{|c|}{0.422415} & $4.260138 * * *$ \\
\hline D(LD_RATE01(-3)) & \multicolumn{2}{|c|}{0.471113} & $5.699098 * * *$ \\
\hline D(LD_RATE01(-4)) & \multicolumn{2}{|c|}{0.358546} & $4.905085 * * *$ \\
\hline D(LY_N01) & \multicolumn{2}{|c|}{1.458784} & $2.887769 * *$ \\
\hline $\mathrm{D}(\mathrm{LPE}(-1))$ & \multicolumn{2}{|c|}{0.475415} & $3.060415 * *$ \\
\hline $\mathrm{D}(\mathrm{LPE}(-2))$ & \multicolumn{2}{|c|}{0.823487} & $3.900936 * * *$ \\
\hline $\mathrm{D}(\mathrm{LPE}(-3))$ & \multicolumn{2}{|c|}{0.954674} & $4.765969 * * *$ \\
\hline $\mathrm{D}(\mathrm{LPE}(-4))$ & \multicolumn{2}{|c|}{0.650933} & $4.501647 * * *$ \\
\hline $\mathrm{D}$ (LAID) & \multicolumn{2}{|c|}{0.199344} & -1.120655 \\
\hline $\mathrm{D}(\operatorname{LAID}(-2))$ & \multicolumn{2}{|c|}{-0.060913} & -1.517292 \\
\hline $\mathrm{D}(\operatorname{LAID}(-3))$ & \multicolumn{2}{|c|}{-0.097493} & $-3.47611 * * *$ \\
\hline \multicolumn{4}{|c|}{ Long-Run Relationship } \\
\hline LM2_GDP01(-1) & \multicolumn{2}{|c|}{0.102860} & 0.936175 \\
\hline LD_RATE01(-1) & \multicolumn{2}{|c|}{0.412415} & $3.843564 * * *$ \\
\hline LY_N01(-1) & \multicolumn{2}{|c|}{2.814235} & $5.620173 * * *$ \\
\hline LPE $(-1)$ & \multicolumn{2}{|c|}{-0.028080} & -0.276079 \\
\hline $\operatorname{LAID}(-1)$ & \multicolumn{2}{|c|}{-0.090103} & -1.089370 \\
\hline $\mathrm{C}$ & \multicolumn{2}{|c|}{-16.98491} & $-5.834405 * * *$ \\
\hline \multicolumn{4}{|c|}{ Diagnostic Tests } \\
\hline R-squared & 0.968674 & Mean dependent var & 0.024578 \\
\hline Adjusted R-squared & 0.848589 & S.D. dependent var & 0.106512 \\
\hline S.E. of regression & 0.041446 & Akaike info criterion & -3.538307 \\
\hline Sum squared resid & 0.010306 & Schwarz criterion & -2.417349 \\
\hline Log likelihood & 77.07460 & F-statistic & 8.066577 \\
\hline Durbin-Watson stat & 2.680687 & Prob(F-statistic) & 0.007762 \\
\hline
\end{tabular}

Note: $* * *$ and $* *$ denote statistical significance at the $1 \%$ and $5 \%$ levels, respectively 
The results reported in Table 6 show that there is a positive relationship between interest rate reforms and bank-based financial deepening in Lesotho. The results apply both in the short run and also in the long run. The short-run positive relationship is supported by the coefficients of the first difference of the lagged interest rate variables in the financial deepening equation, which are found to be positive and statistically significant. The longrun relationship, on the other hand, is supported by the coefficient of the lagged level of interest rate variable in the financial deepening equation, which is positive and statistically significant. Other results show that there is: i) A positive relationship between real GDP and financial deepening in the short run and also in the long run; ii) a positive relationship between the expected inflation and financial deepening in the short run; and iii) a negative relationship between foreign AID and financial deepening in the short run.

\section{CONCLUSION}

In this paper the impact of interest rate reforms on financial deepening in Lesotho is examined using the 1972-2006 data. The study attempts to answer one critical question: Does interest rate liberalisation positively or negatively affect financial deepening in Lesotho? Unfortunately, the majority of previous studies have used either the residual-based cointegration test associated with Engle and Granger (1987) or the maximum likelihood test based on Johansen (1988), and Johansen and Juselius (1990), which may not be appropriate, especially when the sample size is too small (see Nerayan and Smyth, 2005). Using the newly introduced ARDL-Bounds testing approach by Pesaran et al. (2001), the results of the study show that there is a positive relationship between interest rate reforms and bank-based financial deepening in Lesotho. The results apply both in the short run and in the long run. Other results show that: i) An increase in real GDP has a positive effect on financial deepening in Lesotho both in the short run and in the long run; ii) the expected inflation has a positive effect on financial deepening in the short run; and iii) foreign aid has a negative effect on financial deepening in Lesotho in the short run.

\section{AUTHOR INFORMATION}

Professor Nicholas M Odhiambo holds a PhD (Economics) degree from Stellenbosch University (South Africa) and a Masters degree in Economics from the University of Dar-es-salaam (Tanzania). Professor Odhiambo's research profile is broad, rich and multifaceted. During the past ten years, he has published more than 50 articles in 25 recognised journals. Professor Odhiambo is an NRF-rated researcher, and is listed in a number of international bibliographies and databases. Professor Odhiambo is currently working as Professor of Economics and Chair of Growth, Poverty and Policy Modelling Research (GPPMR) flagship at the University of South Africa (UNISA).

\section{REFERENCES}

1. Engle, R.F. and Granger, C.J. (1987), Cointegration and Error-correction - Representation, Estimation and Testing, Econometrica 55 (2): 251-78.

2. $\quad$ English, W.B. (1999), Inflation and Financial Sector Size, Journal of Monetary Economics 44: 379-400.

3. Harris, R. and Sollis, R. (2003), Applied Time Series Modelling and Forecasting, John Wiley, New York.

4. Hendry, D.F. and Ericsson, N. (1991), Modelling the Demand for Narrow Money in the United Kingdom and the United States, European Economic Review 35:833-86.

5. Ikhide, S. (1992), Financial Deepening, Credit Availability and the Efficiency of Investment: Evidence of Selected African Countries, Development Research Paper Series, Research Paper No 2.

6. Johansen, S. and Juselius, K. (1990), Maximum Likelihood Estimation and Inference on Cointegration with Applications to the Demand for Money, Oxford Bulletin of Economics and Statistics 52: 169-210:

7. Matlanyane, A.R. (2002), The Need for Policy Coherence for Financial Liberalisation in Southern Africa: Lessons from a Small Developing Economy, A paper presented at the TIPS Annual Forum - 2002 Glenburn, Muldersdrift.

8. McKinnon, R. (1973), Money and Capital in Economic Development. The Brookings Institution: Washington DC.

9. Mosley, P. (1999), Micro-Macro Linkages in Financial Markets: The Impact of Financial Liberalisation on Access to Rural Credit in Four African Countries, Finance and Development Research Program, Development Initiative, Working Paper No. 4. 
10. Narayan, P.K. and Smyth, R. (2005), Electricity Consumption, Employment and Real Income in Australia: Evidence From Multivariate Granger Causality Tests, Energy Policy 33, 1109-1116.

11. Newey, W.K., West, K.D., 1987. A simple, positive semi-definite, heteroskedasticity and autocorrelation consistent covariance matrix. Econometrica 55, 703-8.

12. Odhiambo, N.M. (2005), Financial Liberalisation and Financial Deepening: Evidence from Three SSA countries, African Review of Money Finance and banking (Savings and Development Supplement): 5-23.

13. Odhiambo, N.M. (2010), Finance-Investment-Growth Nexus: An ARDL-bounds Testing Approach, Economic Change and Restructuring Vol. 43.

14. Pesaran, M.H. and Shin, Y. (1999), An Autoregressive Distributed Lag Modelling Approach to Cointegration Analysis, in Econometrics and Economic Theory in the $20^{\text {th }}$ Century: The Ragnar Frisch Centennial Symposium, eds. Storm, S., Cambridge University Press, Chapter 11, pp.1-31.

15. Pesaran, M.H., Shin, Y. and Smith, R. (2001), Bound Testing Approaches to the Analysis of Level Relationship, Journal of Applied Econometrics 16: 174-89.

16. Seliali, F. and Tlali, K. (1996), Capital Flow Survey, Central Bank of Lesotho. 
NOTES 